\title{
RIVIEW JURNAL
}

\section{Distribution of Seafood Production in Bajo Sector of \\ Gorontalo Province Indonesia}

\author{
NAMA/NIM : ALDY M. HILAHAPA (1121418035)
}

\section{JURUSAN TEKNOLOGI HASIL PERIKANAN}

\begin{abstract}
ABSTRAK
The research was conducted in Bajo Tilamuta Village, Boalemo Regency, Gorontalo Province. Marketing is one of the most important activities in the marketing of Bajo Desa seafood in Boalemo, because one of the obstacles faced is the availability of water infrastructure. In Bajo Village, which happens to be in the Lemito area, Boalemo Regency has high fisheries potential, such as cucumbers and sea pearls, Mapei, Japan. The purpose of this research is to study the economic situation of the Bajo Tilamuta community in Boalemo Village who are fishermen who live, produce and sell. The results of this study provide information that sea cucumbers are classified as having good marketing efficiency and effective marketing if the marketing efficiency of shellfish, mapei and japing is not high.
\end{abstract}

\section{PRELIMINARY}

The development of fisheries is part of national development, and the main objective of fisheries subsector development is carried out by the Indonesian people themselves, both in production, processing and sales. In addition to improving facilities and infrastructure to increase fishermen and fish cultivator incomes, the expansion of the fisheries sub-sector is also aimed at reducing damage to resources and sources of foreign exchange caused by non-oil and gas commodities. Marketing is one of the most important activities to help increase fishermen's income. Marketing is one of the most important activities to improve the economy, especially in the fisheries sector. In selling marine products, it is necessary to provide facilities and infrastructure such as fishing ports, fish markets, etc. The Bajo fishermen in Boalemo Regency produce seafood such as: sea cucumber, mother shell, Mabe shell and Japing shell. Mubyarto (1985) states, Marketing or distribution is a kind of economic activity that serves to bring or deliver goods from producers to consumers. Hippy (1992), that the types of marine products in the village of Bajo Boalemo are fish such as tude, skipjack, mullet, sea cucumber and shellfish.As far as observations, so far no research has been conducted to reveal data and information about the efficiency of Bajo fishermen, therefore the author believes that research is needed to find out more information about this aspect. 


\section{METHODS}

The method used is the sampling method or sampling, because a previous survey has been conducted, the sample village is Bajo Tilamuta Village in Boalemo Regency, and most of the population is the Bajo Tribe. When data analysis uses margin trading as a measure, how many producers divide the market price by the average price? According to Sutarno (2014), the amount of marketing profit can be calculated mathematically based on the formula.

$\mathrm{MP}=\mathrm{Pr}-\mathrm{Pf}$

MP: Margin Marketing

Pr: Prices at the retailer level

Pf: Prices at the fisherman level

The farmers section $\mathrm{LP}=$

He-M x $100 \%$

$\mathrm{He}$

LP: Prices received by fishermen

M: Total Margin $(\mathrm{Rp} / \mathrm{kg})$

He: Retail price at the production level

HK: Price on Consumer

\section{RESULTS AND DISCUSSION}

Average price / $\mathrm{kg}$ of this type of seafood can be seen in the table below:

Table 1. Average Prices at Fisherman's level, Wholesaler Traders and wholesalers

\begin{tabular}{|c|c|c|c|c|}
\hline \multirow{2}{*}{ No } & \multirow{2}{*}{ Type of seafood } & \multirow{2}{*}{$\begin{array}{c}\text { Fishermen } \\
\text { Average }\end{array}$} & $\begin{array}{c}\text { Collecting } \\
\text { Merchants }\end{array}$ & $\begin{array}{c}\text { Wholesalers } \\
\text { Collectors }\end{array}$ \\
\hline 1 & & & 170000 & 190000 \\
2 & Sea Cucumber & 140000 & 29000 & 34000 \\
3 & Shellfish Pearl & 26000 & 22000 & 27000 \\
4 & ShellfishMabe & 18000 & 18000 & 24000 \\
\hline
\end{tabular}

Too see the marketing officency of outhors using farmer share (FS) can be seen from the following calculation:

1. The average price of sea cucumber is: $190000-14000=50,000$ Margin : 50,000

Fharmer share $\quad: \frac{140000-50000}{140000} \times 100 \%$ 
2. The average price of pearl shells is: $34000-26000=8000$

Margin 8000

Fharmer share $: \underline{26000-8000} \times 100 \%$

$$
26000
$$

: $69 \%$

3. The average price of mabe's shell is: $27000-18000=9000$

Margin 9000

Fharmer share $: \underline{18000-9000} \times 100 \%$

18000

$: 50 \%$

4. The average price of japing shell is: $24000-14000=10000$

Margin : :10000

Fharmer share $: \underline{14000-10000 \times 100 \%}$

14000

$: 28 \%$

It can be seen from Table 1 above that compared to collector fishermen, large traders and fishermen have a large profit margin.

Meanwhile, the profit margin between fishermen and fundraising traders is smaller than that of wholesalers. To find out the efficiency of seafood marketing, you can see the table below:

Table 2. Marketing Efficiency of Seafood in Bajo Tilamuta Village, Boalemo Regency.

\begin{tabular}{|c|c|c|c|}
\hline No & Name Of Seafood & Results Precentage(\%) & Marketing Efficiency \\
\hline 1 & Sea Cucumber & 64 & Efficient \\
2 & Pearl Shellfish & 69 & Efficient \\
3 & Mabe Shellfish & 50 & Efficient \\
4 & Japing Shellfish & 28 & Not Efficient \\
\hline
\end{tabular}

Cucumbers, main shells and horse shells have an effective sale because the percentage of income earned at the producer level is 50\%. The purpose of margin marketing is to determine the efficiency of product sales at the producer to consumer level. Marketing profit margin is the difference between the price of each marketing agent participating in marketing activities and the amount of profit. The composition of the cost of the marketing model for each channel is different, so it will affect the marketing profits of the marketing agencies in Bajo Tilamuta Village, Boalemo Regency. 


\section{CONCLUSION}

The most efficient marketing chanel for Bajo fishery products in Boalemo are Sea Cucumber, Pearl Shells, and Mabe Shell. The highest share of farmers in the marketing channels of Shell fish pearl.

\section{REFERENCE}

Yapanto LM, Musa Farid TH. 2018. Distribution of Seafood Production in Bajo Sector of Gorontalo Province Indonesia. International Journal of Innovative Science and Research Technology. 3(8): 521-523 